\title{
Syntheses and Antibacterial Studies of Some 1-Phenyl-3-(4-(2-ethanoloxy) phenyl)-5-aryl-1H-pyrazoles
}

\author{
Anju Goyal, ${ }^{1}$ and Sandeep Jain ${ }^{2}$ \\ ${ }^{1}$ Chitkara College of Pharmacy, Patiala, Rajpura 140401, India \\ ${ }^{2}$ Drug Discovery and Research Laboratory, Department of Pharmaceutical Sciences, Guru Jambheshwar University of Science and \\ Technology, Hisar 125001, India
}

Correspondence should be addressed to Sandeep Jain; drsjain1969@yahoo.co.in

Received 1 March 2012; Accepted 20 May 2012

Academic Editor: Alexander M. Kirillov

Copyright (C) 2013 A. Goyal and S. Jain. This is an open access article distributed under the Creative Commons Attribution License, which permits unrestricted use, distribution, and reproduction in any medium, provided the original work is properly cited.

\begin{abstract}
A series of 1-phenyl-3-(4-(2-ethanoloxy) phenyl)-5-aryl-1H-pyrazoles were synthesized from chalcones, that is, 3-aryl-1-(4hydroxyphenyl) prop-2-en-1-ones and studied for their in vitro antibacterial activity. Chalcones 1 on reaction with phenyl hydrazine in the presence of acetic acid and few drops of hydrochloric acid yielded the corresponding 1-phenyl-3-(4-hydroxyphenyl)-5aryl-1H-pyrazoles 2 which on further reaction with 2-chloroethanol furnished the title compounds 3 . These compounds were characterized by $\mathrm{CHN}$ analyses, IR, mass and ${ }^{1} \mathrm{H}$ NMR spectral data. All the compounds were evaluated for their in vitro antibacterial activity against two Gram positive strains (Bacillus subtilis and Staphylococcus aureus) and two Gram negative strains (Escherichia coli and Pseudomonas aeruginosa), and their minimum inhibitory concentration (MIC) was determined.
\end{abstract}

\section{Introduction}

The extensive utilization of chemotherapeutic agents for the management of infectious diseases leads to the development of microbial resistance to existing drugs. The appearance of resistance to the major classes of antibacterial drugs is recognized as a major health concern of world population. This opens the gate for the medicinal chemists for the development of novel antimicrobial drugs having a different mechanism of action to combat the problem of multidrug resistance [1]. Heterocyclic compounds continue to attract considerable interest due to their diverse biological activities. Amongst them five membered heterocyclic compounds occupy a unique place in the field of natural and synthetic organic chemistry. Five membered heterocycles like pyrazoles have been found to display wide application as pharmaceutical and agrochemical agents. In recent years, attention has increasingly been given to the synthesis of pyrazole derivatives as a source of new antibacterial agents. Pyrazole derivatives have been reported to possess diverse biological activities such as antibacterial $[2,3]$, antifungal $[4,5]$, herbicidal [6], insecticidal [7], anti-inflammatory [8,9] anticonvulsant [10], antitumor [11], anti-oxidant [12] and so forth. Further, $1 \mathrm{H}$-pyrazoles containing phenoxy propanol [13] and phenoxy butanol [14] side chain have been reported to possess antibacterial activity by us as a part of our ongoing research program in the field of synthesis and antimicrobial activity of medicinally important heterocyclic compounds $[15,16]$. These reports inspired us to undertake the synthesis of some $1 H$-pyrazoles bearing phenoxy ethanol moiety. The synthesized compounds were characterized on the basis of elemental analysis, IR, ${ }^{1} \mathrm{H}$ NMR and mass spectral data. All the compounds were screened for their in vitro antibacterial activity against two Gram positive strains (Bacillus subtilis and Staphylococcus aureus) and two Gram negative strains (Escherichia coli and Pseudomonas aeruginosa), respectively.

\section{Experimental}

2.1. Chemistry. The purity of all the synthesized compounds was checked by thin-layer chromatography on silica gel $\mathrm{G}$ as a stationary phase and different solvent systems as a mobile phase using iodine vapors as detecting agent. Melting points were determined by the Tempo melting point determination apparatus in open capillary tubes and are 
uncorrected. Elemental analyses were carried out on Perkin Elmer $2400 \mathrm{CHN}$ Elemental Analyser. Infrared spectra were recorded on Shimadzu 8000 FTIR Spectrophotometer in $\mathrm{KBr}$ phase. Proton NMR spectra were done on Bruker Avance II 400 NMR Spectrometer using tetramethyl silane as internal standard. Mass spectra of the compounds were carried out on Waters Micromass Q-Tof Micro Mass Spectrometer using electrospray ionization (ESI) technique. Chalcones 1a-g were synthesized by a base-catalyzed Claisen-Schmidt condensation reaction of appropriately substituted benzaldehydes and p-hydroxy acetophenone [17], and 1-phenyl-3(4-hydroxyphenyl)-5-aryl-1H-pyrazoles $\mathbf{2 a - g}$ were prepared from the chalcones $\mathbf{1 a}-\mathbf{g}$ following the procedure described in the literature [18].

2.2. General Procedure for the Synthesis of 1-phenyl-3-(4-(2ethanoloxy) phenyl)-5-aryl-1H-pyrazoles (3a-g). 1-Phenyl-3(4-hydroxyphenyl)-5-aryl-1H-pyrazoles (2a-g $0.01 \mathrm{M})$ and 2-chloroethanol $(0.01 \mathrm{M})$ were refluxed in acetone $(50 \mathrm{~mL})$ in the presence of triethylamine $(0.01 \mathrm{M})$ for about four hours. Excess of solvent was removed under reduced pressure. The residue thus obtained was washed thoroughly with cold distilled water, dried, and then recrystallized from ethanol. The physical and analytical data of the synthesized title compounds are given as follows.

1,5-Diphenyl-3-(4-(2-ethanoloxy) phenyl)-1H-pyrazole (3a): Yield: 69\%; m.p.: $74-76^{\circ} \mathrm{C}$; IR $\left(\mathrm{KBr}, \mathrm{cm}^{-1}\right) 3340$ (O-H), 3063 (aromatic C-H str), 2917 (C-H), 1465 $\left(\mathrm{CH}_{2}\right), 1256$ (C-O-C), 1065 (C-O), 830, 732, and 691 (aromatic $\mathrm{C}-\mathrm{H}$ def); ${ }^{1} \mathrm{HNMR}\left(\mathrm{CDCl}_{3}\right): \delta$ (ppm) 8.06-7.08 (m, 14H, ArH), 7.02 (s, 1H, =CH-), 4.33-4.31 $\left(\mathrm{t}, 2 \mathrm{H}, \mathrm{HO}-\mathrm{CH}_{2}-\mathrm{CH}_{2}-\mathrm{O}-\mathrm{Ar}\right), \quad 3.59-3.57 \quad(\mathrm{t}, \quad 2 \mathrm{H}$, $\left.\mathrm{HO}-\mathrm{CH}_{2}-\mathrm{CH}_{2}-\mathrm{O}-\mathrm{Ar}\right), 3.65$ (s, $\left.1 \mathrm{H}, \mathrm{O}-\mathrm{H}\right) ; \mathrm{MS}, \mathrm{m} / \mathrm{z}$ (\%): $357[\mathrm{M}+\mathrm{H}]^{+}$(100\%). Anal.: Calcd. For $\mathrm{C}_{23} \mathrm{H}_{20} \mathrm{~N}_{2} \mathrm{O}_{2}$ : C, 77.51; H, 5.66; N, 7.86. Found: C, 77.56; H, 5.61; N, 7.80.

1-Phenyl-3-(4-(2-ethanoloxy) phenyl)-5-(4-methylphenyl)-1H-pyrazole (3b): Yield: $72 \%$; m.p.: $66-68^{\circ} \mathrm{C}$; IR $\left(\mathrm{KBr}, \mathrm{cm}^{-1}\right)$ : $3342(\mathrm{O}-\mathrm{H}), 3065$ (aromatic C-H str), 2916 $(\mathrm{C}-\mathrm{H}), 1465\left(\mathrm{CH}_{2}\right), 1255(\mathrm{C}-\mathrm{O}-\mathrm{C}), 1065(\mathrm{C}-\mathrm{O}), 830$, 730 , and 692 (aromatic C-H def); ${ }^{1} \mathrm{HNMR}\left(\mathrm{CDCl}_{3}\right): \delta$ (ppm) 7.68-7.09 (m, 13H, ArH), 7.02 (s, 1H, =CH-), 4.32-4.30 (t, 2H, HO- $\left.\mathrm{CH}_{2}-\mathrm{CH}_{2}-\mathrm{O}-\mathrm{Ar}\right), 3.58-3.56(\mathrm{t}, 2 \mathrm{H}$, $\left.\mathrm{HO}-\mathrm{CH}_{2}-\mathrm{CH}_{2}-\mathrm{O}-\mathrm{Ar}\right), 3.65(\mathrm{~s}, 1 \mathrm{H}, \mathrm{O}-\mathrm{H}), 2.34(\mathrm{~s}, 3 \mathrm{H}$, $\left.\mathrm{CH}_{3}-\mathrm{Ar}\right) ; \mathrm{MS}, \mathrm{m} / \mathrm{z}(\%): 371[\mathrm{M}+\mathrm{H}]^{+}$(100\%). Anal.: Calcd. For $\mathrm{C}_{24} \mathrm{H}_{22} \mathrm{~N}_{2} \mathrm{O}_{2}$ : C, 77.81; H, 5.99; N, 7.56. Found: C, 77.87; $\mathrm{H}, 5.92 ; \mathrm{N}, 7.50$.

1-Phenyl-3-(4-(2-ethanoloxy) phenyl)-5-(4-methoxy-phenyl)-1H-pyrazole (3c): Yield: 64\%; m.p.: 95-97 C; IR (KBr, $\mathrm{cm}^{-1}$ ): $3340(\mathrm{O}-\mathrm{H}), 3063$ (aromatic C-H str), $2919(\mathrm{C}-\mathrm{H})$, $1465\left(\mathrm{CH}_{2}\right), 1255(\mathrm{C}-\mathrm{O}-\mathrm{C}), 1066(\mathrm{C}-\mathrm{O}), 831,732$, and 690 (aromatic C-H def); ${ }^{1} \mathrm{HNMR}\left(\mathrm{CDCl}_{3}\right): \delta$ (ppm) 7.63-7.08 $(\mathrm{m}, 13 \mathrm{H}, \operatorname{ArH}), 7.01$ (s, 1H, $=\mathrm{CH}-), 4.33-4.31(\mathrm{t}, 2 \mathrm{H}$, $\mathrm{HO}-\mathrm{CH}_{2}-\mathrm{CH}_{2}-\mathrm{O}-\mathrm{Ar}$ ), 3.83 (s, 3H, $\mathrm{CH}_{3} \mathrm{O}-\mathrm{Ar}$ ), 3.59-3.57 (t, 2H, HO-CH $\mathrm{CH}_{2}-\mathrm{CH}_{2}-\mathrm{O}-\mathrm{Ar}$ ), 3.65 (s, 1H, O-H); MS, m/z (\%): $387[\mathrm{M}+\mathrm{H}]^{+}$(100\%). Anal.: Calcd. For $\mathrm{C}_{24} \mathrm{H}_{22} \mathrm{~N}_{2} \mathrm{O}_{3}$ : C, 74.59; H, 5.74; N, 7.25. Found: C, 74.52; H, 5.79, N, 7.31.

1-Phenyl-3-(4-(2-ethanoloxy) phenyl)-5-(4-chlorophenyl)$1 \mathrm{H}$-pyrazole (3d): Yield: $71 \%$; m.p.: $78-80^{\circ} \mathrm{C}$; IR (KBr, $\left.\mathrm{cm}^{-1}\right): 3342(\mathrm{O}-\mathrm{H}), 3068$ (aromatic C-H str), 2919 $(\mathrm{C}-\mathrm{H}), 1460\left(\mathrm{CH}_{2}\right), 1253(\mathrm{C}-\mathrm{O}-\mathrm{C}), 1066$ (C-O), 833, 733, and 690 (aromatic C-H def); ${ }^{1} \mathrm{HNMR}\left(\mathrm{CDCl}_{3}\right): \delta$ (ppm) 8.03-7.08 (m, 13H, ArH), 7.02 (s, 1H, =CH-), 4.32-4.30 (t, 2H, $\left.\mathrm{HO}-\mathrm{CH}_{2}-\mathrm{CH}_{2}-\mathrm{O}-\mathrm{Ar}\right), 3.56-3.54(\mathrm{t}, 2 \mathrm{H}$, $\mathrm{HO}-\mathrm{CH}_{2}-\mathrm{CH}_{2}-\mathrm{O}-\mathrm{Ar}$ ), 3.65 (s, $\left.1 \mathrm{H}, \mathrm{O}-\mathrm{H}\right) ; \mathrm{MS}, \mathrm{m} / \mathrm{z}(\%)$ : $391[\mathrm{M}+\mathrm{H}]^{+}(100 \%), 393[\mathrm{M}+2+\mathrm{H}]^{+}$(35\%). Anal.: Calcd. For $\mathrm{C}_{23} \mathrm{H}_{19} \mathrm{ClN}_{2} \mathrm{O}_{2}$ : C, 70.68; H, 4.90; N, 7.17. Found: C, $70.61 ; \mathrm{H}, 4.97 ; \mathrm{N}, 7.12$.

1-Phenyl-3-(4-(2-ethanoloxy) phenyl)-5-(4-bromo-phenyl)-1H-pyrazole (3e): Yield: 76\%; m.p.: 87-89 C; IR $\left(\mathrm{KBr}, \mathrm{cm}^{-1}\right)$ : $3340(\mathrm{O}-\mathrm{H}), 3065$ (aromatic C-H str), 2916 $(\mathrm{C}-\mathrm{H}), 1463\left(\mathrm{CH}_{2}\right), 1255(\mathrm{C}-\mathrm{O}-\mathrm{C}), 1065(\mathrm{C}-\mathrm{O}), 831$, 731, and 692 (aromatic C-H def); ${ }^{1} \mathrm{HNMR}\left(\mathrm{CDCl}_{3}\right): \delta$ (ppm) 7.79-7.09 (m, 13H, ArH), 7.02 (s, 1H, =CH-), 4.32-4.30 (t, 2H, HO- $\left.\mathrm{CH}_{2}-\mathrm{CH}_{2}-\mathrm{O}-\mathrm{Ar}\right), 3.56-3.54(\mathrm{t}, 2 \mathrm{H}$, $\left.\mathrm{HO}-\mathrm{CH}_{2}-\mathrm{CH}_{2}-\mathrm{O}-\mathrm{Ar}\right), 3.65$ (s, $\left.1 \mathrm{H}, \mathrm{O}-\mathrm{H}\right) ; \mathrm{MS}, \mathrm{m} / \mathrm{z}(\%)$ : $435[\mathrm{M}+\mathrm{H}]^{+}(100 \%), 437[\mathrm{M}+2+\mathrm{H}]^{+}$(98\%). Anal.: Calcd. For $\mathrm{C}_{23} \mathrm{H}_{19} \mathrm{BrN}_{2} \mathrm{O}_{2}$ : C, 63.46; $\mathrm{H}, 4.40 ; \mathrm{N}, 6.44$. Found: $\mathrm{C}$, 63.41; H, 4.46; N, 4.49.

1-Phenyl-3-(4-(2-ethanoloxy) phenyl)-5-(4-fluorophenyl)1H-pyrazole (3f): Yield: 69\%; m.p.: $78-80^{\circ} \mathrm{C}$; IR (KBr, $\left.\mathrm{cm}^{-1}\right): 3344$ (O-H), 3066 (aromatic C-H str), 2918 $(\mathrm{C}-\mathrm{H}), 1465\left(\mathrm{CH}_{2}\right), 1255$ (C-O-C), 1065 (C-O), 832, 730, and 692 (aromatic C-H def); ${ }^{1} \mathrm{HNMR}\left(\mathrm{CDCl}_{3}\right): \delta$ (ppm) 8.16-7.08 (m, 13H, ArH), 7.01 (s, 1H, =CH-), 4.33-4.31 (t, 2H, HO- $\left.\mathrm{CH}_{2}-\mathrm{CH}_{2}-\mathrm{O}-\mathrm{Ar}\right), 3.57-3.55$ (t, $2 \mathrm{H}$, $\mathrm{HO}-\mathrm{CH}_{2}-\mathrm{CH}_{2}-\mathrm{O}-\mathrm{Ar}$ ), 3.65 (s, $\left.1 \mathrm{H}, \mathrm{O}-\mathrm{H}\right) ; \mathrm{MS}, \mathrm{m} / \mathrm{z}$ (\%): $375[\mathrm{M}+\mathrm{H}]^{+}$(100\%). Anal.: Calcd. for $\mathrm{C}_{23} \mathrm{H}_{19} \mathrm{FN}_{2} \mathrm{O}_{2}$ : C, 73.78; H, 5.11; N, 7.48. Found: C, 73.72; H, 5.17; N, 7.41.

1-Phenyl-3-(4-(2-ethanoloxy) phenyl)-5-(4-nitrophenyl)1H-pyrazole (3g): Yield: 68\%; m.p.: $61-63^{\circ} \mathrm{C}$; IR (KBr, $\left.\mathrm{cm}^{-1}\right)$ : 3340 (O-H), 3060 (aromatic C-H str), 2916 $(\mathrm{C}-\mathrm{H}), 1465\left(\mathrm{CH}_{2}\right), 1256(\mathrm{C}-\mathrm{O}-\mathrm{C}), 1070(\mathrm{C}-\mathrm{O}), 830$, 732, and 691 (aromatic $\mathrm{C}-\mathrm{H}$ def); ${ }^{1} \mathrm{HNMR}\left(\mathrm{CDCl}_{3}\right): \delta$ (ppm) 8.32-7.08 (m, 13H, ArH), 7.02 (s, 1H, =CH-), 4.33-4.31 (t, 2H, HO- $\left.\mathrm{CH}_{2}-\mathrm{CH}_{2}-\mathrm{O}-\mathrm{Ar}\right), 3.58-3.56(\mathrm{t}, 2 \mathrm{H}$, $\mathrm{HO}-\mathrm{CH}_{2}-\mathrm{CH}_{2}-\mathrm{O}-\mathrm{Ar}$ ), 3.65 (s, $\left.1 \mathrm{H}, \mathrm{O}-\mathrm{H}\right) ; \mathrm{MS}, \mathrm{m} / \mathrm{z}(\%)$ : $402[\mathrm{M}+\mathrm{H}]^{+}(100 \%)$. Anal.: Calcd. For $\mathrm{C}_{23} \mathrm{H}_{19} \mathrm{~N}_{3} \mathrm{O}_{4}$ : C, 68.82; H, 4.77; N,10.47. Found: C, 68.87; H, 4.71; N, 10.42.

2.3. Antibacterial Activity. All the title compounds were screened for their in vitro antibacterial activity against two Gram positive strains, that is, Bacillus subtilis (MTCC 121) and Staphylococcus aureus (MTCC 96) and two Gram negative strains, that is, Escherichia coli (MTCC 40) and Pseudomonas aeruginosa (MTCC 2453), respectively. Ciprofloxacin was used as the standard drug for the present study. Serial two-fold dilution technique was used for the study of antibacterial activity [19]. A stock solution $(10 \mu \mathrm{g} / \mathrm{mL})$ of all the title compounds and standard drug was prepared in dimethyl sulfoxide. Sterilized double-strength nutrient broth (DSNB) was used as a growth media. The stock solution was serially diluted by DSNB aseptically to give concentrations of $5.0-0.01 \mu \mathrm{g} / \mathrm{mL}$ into a series of sterilized culture tubes. All the tubes were inoculated by bacterial strain. The inoculum's size was approximately $10^{6}$ 
colony forming units $(\mathrm{CFU} / \mathrm{mL})$. The inoculated tubes were incubated for $24 \mathrm{~h}$ at $37( \pm 1)^{\circ} \mathrm{C}$. After $24 \mathrm{~h}$, the inoculated culture tubes were macroscopically examined for turbidity. The culture tube showing turbidity (lower concentration) and the culture tube showing no turbidity (higher concentration) gave the minimum inhibitory concentration (MIC) for the compound. The MIC for the title compounds and the standard drug, that is, ciprofloxacin are presented in Table 1.

\section{Result and Discussion}

3.1. Chemistry. The syntheses of 1-phenyl-3-(4-(2-ethanoloxy) phenyl)-5-aryl-1 $H$-pyrazoles were achieved following the steps outlined in Scheme 1. Chalcones, that is, 3-aryl1-(4-hydroxyphenyl) prop-2-en-1-ones, 1 were prepared by the reaction of $p$-hydroxy acetophenone with substituted benzaldehydes following the Claisen-Schmidt reaction. The chalcones $\mathbf{1}$ then on refluxing with phenyl hydrazine in the presence of acetic acid and few drops of hydrochloric acid furnished 1-phenyl-3-(4-hydroxyphenyl)-5-aryl- $1 \mathrm{H}$ pyrazoles 2. Reaction of 2-chloroethanol with 2 in the presence of triethyl amine yielded the title compounds $\mathbf{3}$. All the compounds were obtained in good yield. These compounds were characterized on the basis of elemental and spectral analyses. IR spectra of each compound showed a band for $\mathrm{O}-\mathrm{H}$ stretching vibrations for intermolecular hydrogen bonding near $3340 \mathrm{~cm}^{-1}$, while the $\mathrm{C}-\mathrm{O}$ stretching vibrations for primary alcohols were observed in the range of $1085-1050 \mathrm{~cm}^{-1}$. The $\mathrm{C}-\mathrm{O}-\mathrm{C}$ stretching vibrations for aryl alkyl ethers appeared near $1255 \mathrm{~cm}^{-1}$. The $\mathrm{C}-\mathrm{H}$ stretching vibrations for methylene groups appeared in the range of $2916-2919 \mathrm{~cm}^{-1}$, whereas bending vibrations for methylene scissoring were observed constantly at $1465 \mathrm{~cm}^{-1}$. Aromatic $\mathrm{C}-\mathrm{H}$ stretching vibrations were observed in the range of $3100-3050 \mathrm{~cm}^{-1}$, whereas aromatic $\mathrm{C}-\mathrm{H}$ bending vibrations appeared below $900 \mathrm{~cm}^{-1}$. In case of ${ }^{1} \mathrm{H} \mathrm{NMR}$, the chemical shift value for the $\mathrm{O}-\mathrm{H}$ group was observed in the range of $3.70-3.65 \delta(\mathrm{ppm})$ and appeared as singlet (s). Aromatic protons appeared as multiplet $(\mathrm{m})$ in the range of $8.33-7.08 \delta(\mathrm{ppm})$. The methine proton of the pyrazole nucleus absorbed at 7.03-7.01 $\delta(\mathrm{ppm})$ and appeared as singlet (s). The methylene protons adjacent to the $\mathrm{O}-\mathrm{H}$ group [ $\mathrm{HO}-\mathrm{CH}_{2}-\mathrm{CH}_{2}-\mathrm{O}-\mathrm{Ar}$ ] appeared as triplet $(\mathrm{t})$ in the range of $3.59-3.51 \delta(\mathrm{ppm})$, whereas the methylene protons adjacent to the $\mathrm{O}-\mathrm{Ar}$ group $\left[\mathrm{HO}-\mathrm{CH}_{2}-\mathrm{CH}_{2}-\mathrm{O}-\mathrm{Ar}\right]$ observed at $4.33-4.06 \delta(\mathrm{ppm})$ and also appeared as triplet $(\mathrm{t})$. Aromatic methyl and methoxy protons were observed at $2.36-2.34 \delta(\mathrm{ppm})$ and $3.85-3.83 \delta(\mathrm{ppm})$, respectively as singlet (s). All the title compounds showed $[\mathrm{M}+\mathrm{H}]^{+}$of $100 \%$ intensity as the molecular ion peak. Compound containing chlorine showed isotopic peak at $[\mathrm{M}+2+\mathrm{H}]^{+}$of about $35 \%$ intensity to that of parent ion peak, whereas bromo derivative showed isotopic peak at $[\mathrm{M}+2+\mathrm{H}]^{+}$of about equal intensity. The results of elemental analyses were found in good agreement with the calculated values.

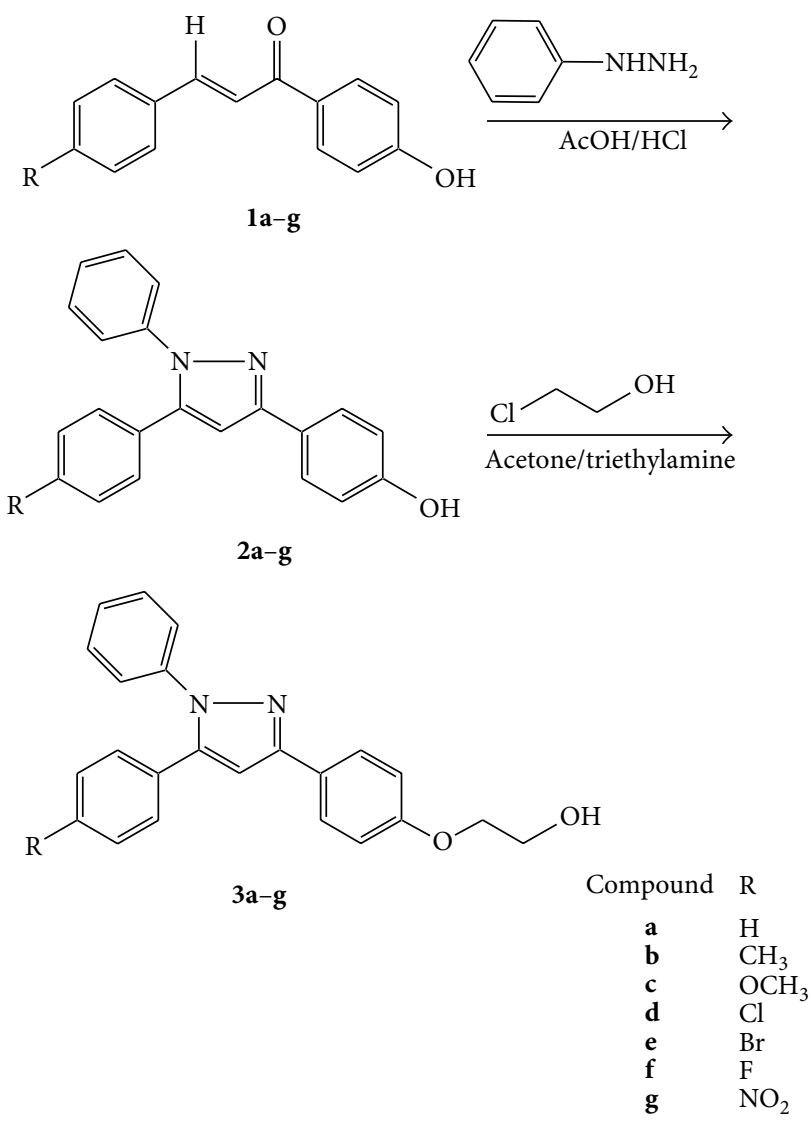

Scheme 1: Synthesis of 1-Phenyl-3-(4-(2-ethanoloxy) phenyl)-5aryl- $1 H$-pyrazoles.

3.2. Antibacterial Activity. All the synthesized title compounds were screened for their in vitro antibacterial activity against and two Gram positive bacterial strains, that is, Bacillus subtilis (MTCC 121) and Staphylococcus aureus (MTCC 96) and two Gram negative bacterial strains, that is, Escherichia coli (MTCC 40) and Pseudomonas aeruginosa (MTCC 2453), respectively, and their minimum inhibitory concentration (MIC) was determined. A perusal of the Table 1 shows that all the title compounds were found to be active against all the bacterial strains used in this study. However, they showed more activity against the Gram negative than the Gram positive bacterial strains. Out of the two Gram negative bacterial strains, E. coli (MTCC 40) was found to be more susceptible than $P$. aeruginosa (MTCC 2453) against all the title compounds. The minimum inhibitory concentration (MIC) of the title compounds $\mathbf{3 a - g}$ was found to be $0.45-0.30 \mu \mathrm{g} / \mathrm{mL}, 0.50-0.35 \mu \mathrm{g} / \mathrm{mL}, 0.55-0.40 \mu \mathrm{g} / \mathrm{mL}$, and $0.55-0.45 \mu \mathrm{g} / \mathrm{mL}$ against E. coli (MTCC 40), P. aeruginosa (MTCC 2453), B. subtilis (MTCC 121) and S. aureus (MTCC 96), respectively. The MICs of the title compounds containing electron withdrawing groups like fluoro, chloro, bromo, or nitro were found somewhat less than the compounds containing electron releasing groups like methyl and methoxy. The reference standard ciprofloxacin inhibited 
TABLE 1: In vitro antibacterial activity of 1-phenyl-3-(4-(2-ethanoloxy) phenyl)-5-aryl-1H-pyrazoles (3a-g).

\begin{tabular}{lcccc}
\hline Compound & \multicolumn{3}{c}{$\begin{array}{c}\text { Minimum inhibitory concentration }(\mu \mathrm{g} / \mathrm{mL}) \\
\text { E. coli }\end{array}$} & $\begin{array}{c}\text { P. aeruginosa } \\
(\text { MTCC 2453) }\end{array}$ \\
\hline 3a & $\begin{array}{c}\text { S. aureus } \\
\text { (MTCC 121) }\end{array}$ & (MTCC 96) & 0.40 & 0.45 \\
3b & 0.50 & 0.50 & 0.40 & 0.45 \\
3c & 0.50 & 0.50 & 0.45 & 0.50 \\
3d & 0.55 & 0.55 & 0.30 & 0.40 \\
3e & 0.45 & 0.45 & 0.30 & 0.40 \\
3f & 0.45 & 0.45 & 0.30 & 0.40 \\
3g & 0.45 & 0.45 & 0.30 & 0.35 \\
Ciprofloxacin (standard drug) & 0.40 & 0.45 & 0.01 & 0.25 \\
\hline
\end{tabular}

Gram negative bacteria namley, E. coli and $P$. aeruginosa at a $\mathrm{MIC}$ of $0.01 \mu \mathrm{g} / \mathrm{mL}$ and $0.25 \mu \mathrm{g} / \mathrm{mL}$, respectively, whereas against Gram positive bacteria namley, $S$. aureus and $B$. subtilis MIC was found to be $0.15 \mu \mathrm{g} / \mathrm{mL}$ and $0.12 \mu \mathrm{g} / \mathrm{mL}$, respectively. The results of the MIC for the standard drug, ciprofloxacin, against the bacterial strains used were found to be within the range as reported in the literature [20-22].

\section{Conclusion}

The present study describes the synthesis of a series of 1-phenyl-3-(4-(alkanoloxy) phenyl)-5-aryl-1H-pyrazoles starting from the chalcones. The compounds were characterized by modern analytical techniques such as CHN analyses, IR, mass and proton NMR spectra. All the title compounds were screened for their in vitro antibacterial activity against Bacillus subtilis; Staphylococcus aureus (Gram positive) and Escherichia coli; Pseudomonas aeruginosa (Gram negative), and their minimum inhibitory concentration (MIC) was determined. The results of antibacterial activity showed that compounds containing electron withdrawing groups for example, chloro, bromo, fluoro, or nitro were found to be more active than the compounds containing electron releasing groups such as methyl and methoxy. These results suggest that some more compounds using different aromatic or heteroaromatic aldehydes, ketones, and haloalkanols should be synthesized and screened for their antibacterial activity to explore the possibility of 1-phenyl-3-(4(alkanoloxy) phenyl)-5-aryl-1H-pyrazoles as a novel series of antibacterials.

\section{Acknowledgments}

The authors are thankful to the chairman of the Department of Pharmaceutical Sciences, Guru Jambheshwar University of Science and Technology, Hisar, India, for providing necessary facilities to carry out this work. Our sincere thanks are due to Department of SAIF, P.U. Chandigarh for elemental and spectral analysis. The director of IMTECH, Chandigarh, is also duly acknowledged for providing bacterial strains.

\section{References}

[1] R. Sharma, C. L. Sharma, and B. Kapoor, "Antibacterial resistance: current problems and possible solutions," Indian Journal of Medical Sciences, vol. 59, no. 3, pp. 120-129, 2005.

[2] S. M. Gomha and H. M. E. Hassaneen, "Synthesis and antimicrobial activity of some new pyrazoles, fused pyrazolo[3,4d]-pyrimidine and 1,2-dihydroimidazo-[2,1-c][1,2,4]triazin-6one derivatives," Molecules, vol. 16, no. 8, pp. 6549-6560, 2011.

[3] E. S. M. N. Abdel-Hafez, G. E. D. A. A. Abuo-Rahma, M. AbdelAziz, M. F. Radwan, and H. H. Farag, "Design, synthesis and biological investigation of certain pyrazole-3-carboxylic acid derivatives as novel carriers for nitric oxide," Bioorganic and Medicinal Chemistry, vol. 17, no. 11, pp. 3829-3837, 2009.

[4] T. E. Ali, "Synthesis and antibacterial activity of some new thiadiaza/triazaphospholes, thiadiaza/triaza/tetrazaphosphinines and thiadiaza/tetrazaphosphepines containing 1,2,4-triazinone moiety," European Journal of Medicinal Chemistry, vol. 44, no. 11, pp. 4385-4546, 2009.

[5] N. Satheesha Rai, B. Kalluraya, B. Lingappa, S. Shenoy, and V. G. Puranic, "Convenient access to 1,3,4-trisubstituted pyrazoles carrying 5-nitrothiophene moiety via 1,3-dipolar cycloaddition of sydnones with acetylenic ketones and their antimicrobial evaluation," European Journal of Medicinal Chemistry, vol. 43, no. 8, pp. 1715-1720, 2008.

[6] M. Witschel, "Design, synthesis and herbicidal activity of new iron chelating motifs for HPPD-inhibitors," Bioorganic \& Medicinal Chemistry, vol. 17, no. 12, pp. 4221-4229, 2009.

[7] G. P. Lahm, T. M. Stevenson, T. P. Selby et al., "Rynaxypyr: a new insecticidal anthranilic diamide that acts as a potent and selective ryanodine receptor activator," Bioorganic and Medicinal Chemistry Letters, vol. 17, no. 22, pp. 6274-6279, 2007.

[8] A. M. Youssef, M. Sydney White, E. B. Villanueva, I. M. ElAshmawy, and A. Klegeris, "Synthesis and biological evaluation of novel pyrazolyl-2,4-thiazolidinediones as anti-inflammatory and neuroprotective agents," Bioorganic and Medicinal Chemistry, vol. 18, no. 5, pp. 2019-2028, 2010.

[9] P. D. Sauzem, P. Machado, M. A. Rubin et al., "Design and microwave-assisted synthesis of 5-trifluoromethyl-4,5dihydro- $1 H$-pyrazoles: novel agents with analgesic and antiinflammatory properties," European Journal of Medicinal Chemistry, vol. 43, no. 6, pp. 1237-1247, 2008.

[10] M. Abdel-Aziz, G. E. D. A. Abuo-Rahma, and A. A. Hassan, "Synthesis of novel pyrazole derivatives and evaluation of their 
antidepressant and anticonvulsant activities," European Journal of Medicinal Chemistry, vol. 44, no. 9, pp. 3480-3487, 2009.

[11] S. A. F. Rostom, "Polysubstituted pyrazoles, part 6. Synthesis of some 1-(4-chlorophenyl)-4-hydroxy-1H-pyrazol-3-carbonyl derivatives linked to nitrogenous heterocyclic ring systems as potential antitumor agents," Bioorganic \& Medicinal Chemistry, vol. 18, no. 7, pp. 2767-2776, 2010.

[12] E. A. Musad, R. Mohamed, B. A. Saeed, B. S. Vishwanath, and K. M. L. Rai, "Synthesis and evaluation of antioxidant and antibacterial activities of new substituted bis(1,3,4-oxadiazoles), 3,5bis(substituted) pyrazoles and isoxazoles," Bioorganic \& Medicinal Chemistry Letters, vol. 21, no. 12, pp. 3536-3540, 2011.

[13] A. Goyal and S. Jain, "Synthesis and antibacterial screening of some 1- phenyl-3-(4-(3-propanoloxy) phenyl)-5-aryl-1Hpyrazoles," Der Chemica Sinica, vol. 3, no. 1, p. 249, 2012.

[14] A. Goyal and S. Jain, "Syntheses and antibacterial activity of some 1-phenyl-3-(4-(4-butanoloxy) phenyl)-5-aryl-1Hpyrazoles," Der Pharma Chemica, vol. 4, no. 1, pp. 234-241, 2012.

[15] S. Jain, A. Kumar, M. Kumar, and N. Jain, "Synthesis and antibacterial studies of 2-aryl-3-alkanamido- $4 \mathrm{H}$-thiazolidin-4one derivatives," Arabian Journal of Chemistry. In press.

[16] N. Jain, D. P. Pathak, P. Mishra, and S. Jain, "Syntheses and antibacterial studies of some 2-[5-(Aryl)-[1,3,4] oxadiazole-2ylsulfanyl] alkanoic Acids," Journal of the Iranian Chemical Society, vol. 6, no. 1, pp. 77-81, 2009.

[17] A. A. H. Abdel-Rahman, A. E. S. Abdel-Megied, M. A. M. Hawata, E. R. Kasem, and M. T. Shabaan, "Synthesis and antimicrobial evaluation of some halcones and their derived pyrazoles, pyrazolines, isoxazolines, and 5,6-dihydropyrimidine-2-(1H)-thiones," Monatshefte fur Chemie, vol. 138, no. 9, pp. 889-897, 2007.

[18] A. Voskiene, V. Mickevicius, and G. Mikulskiene, "Synthesis and structural characterization of products condensation 4-carboxy-1-(4-styrylcarbonylphenyl)-2-pyrrolidinones with hydrazines," Arkivoc, vol. 2007, no. 15, pp. 303-314, 2007.

[19] J. G. Cappucino and N. Sherman, Microbiology: A Laboratory Manual, Addison Wesley, San-Francisco, Calif, USA, 1999.

[20] A. Bauernfeind, "Comparison of the antibacterial activities of the quinolones Bay 12-8039, gatifloxacin (AM 1155), trovafloxacin, clinafloxacin, levofloxacin and ciprofloxacin," Journal of Antimicrobial Chemotherapy, vol. 40, no. 5, pp. 639-651, 1997.

[21] J. A. A. Hoogkamp-Korstanje, "In-vitro activities of ciprofloxacin, levofloxacin, lomefloxacin, ofloxacin, pefloxacin, sparfloxacin and trovafloxacin against gram-positive and gram-negative pathogens from respiratory tract infections," Journal of Antimicrobial Chemotherapy, vol. 40, no. 3, pp. 427-431, 1997.

[22] D. J. Weber, S. M. Saviteer, W. A. Rutala, and C. A. Thomann, "In vitro susceptibility of Bacillus spp. to selected antimicrobial agents," Antimicrobial Agents and Chemotherapy, vol. 32, no. 5, pp. 642-645, 1988. 

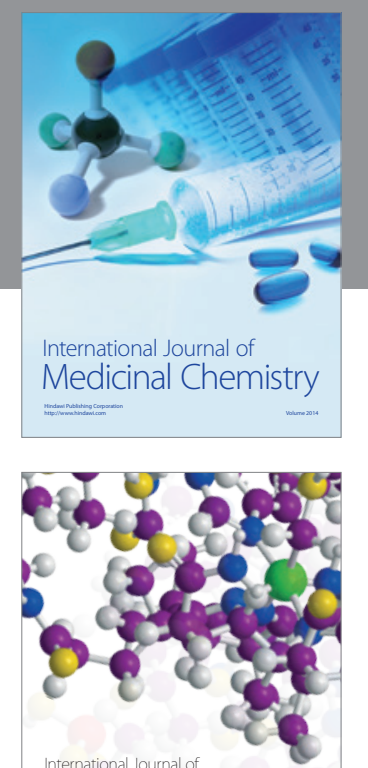

\section{Carbohydrate} Chemistry

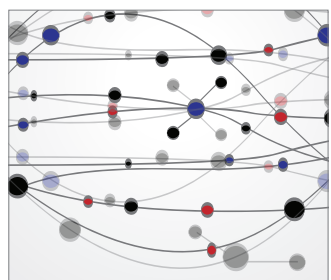

The Scientific World Journal
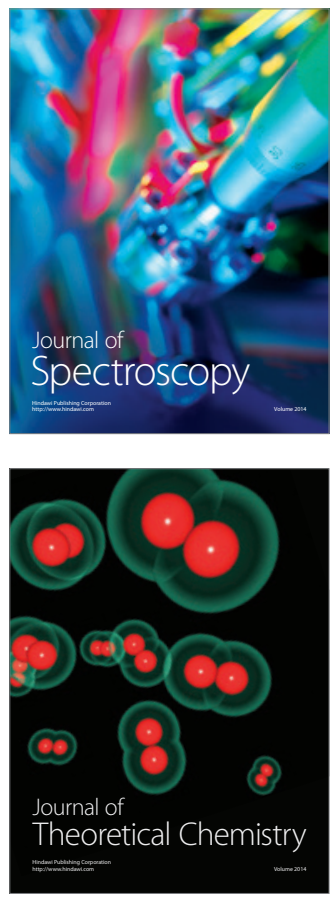
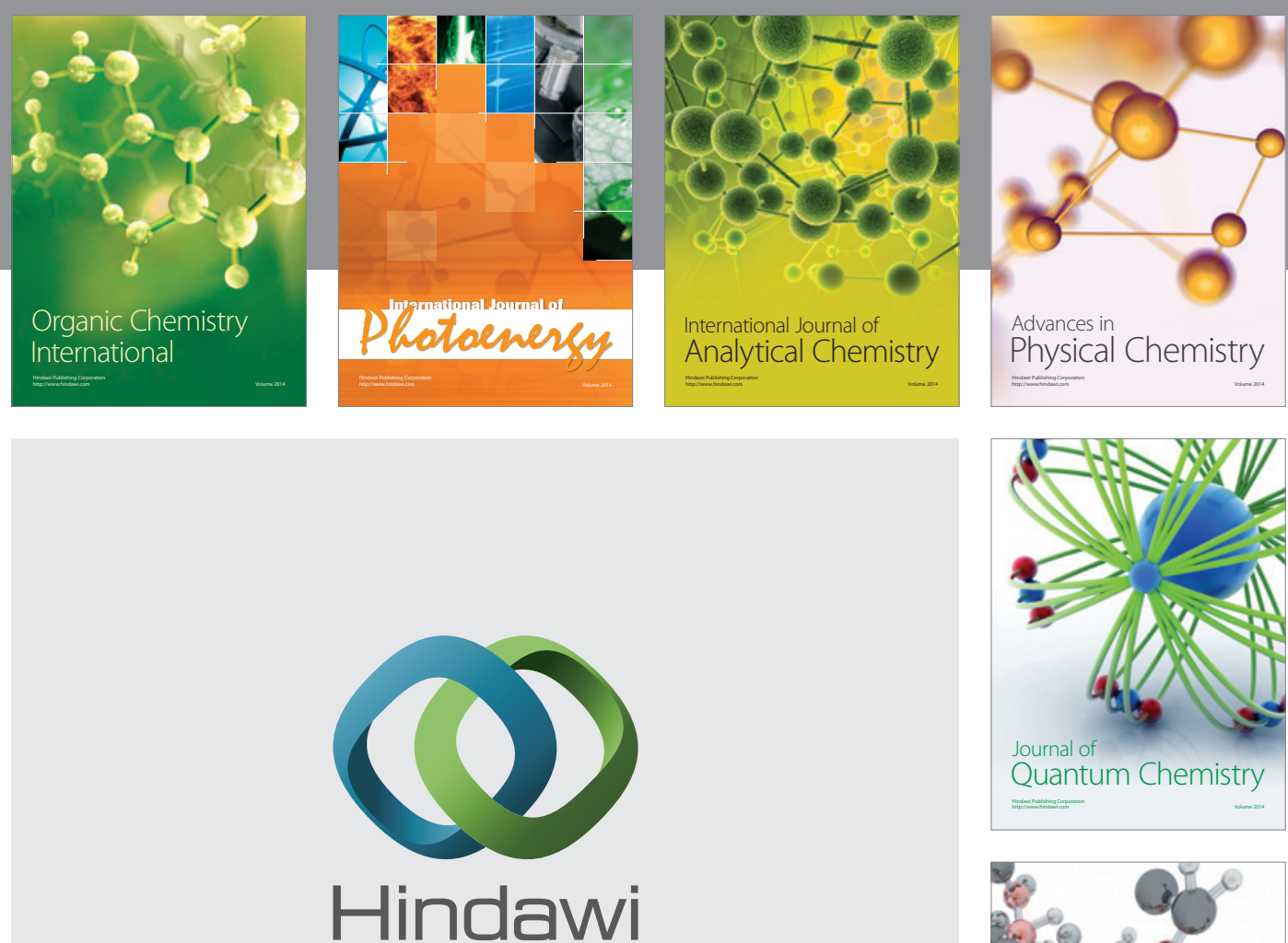

Submit your manuscripts at

http://www.hindawi.com

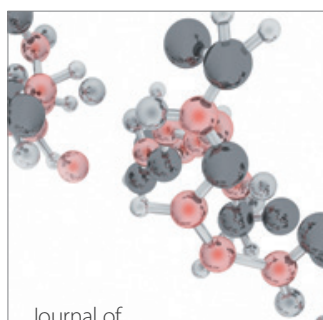

Analytical Methods

in Chemistry

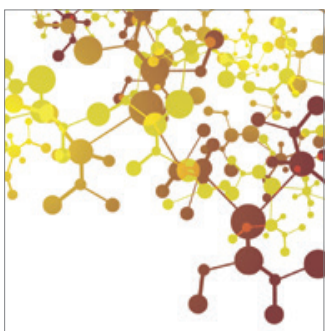

Journal of

Applied Chemistry

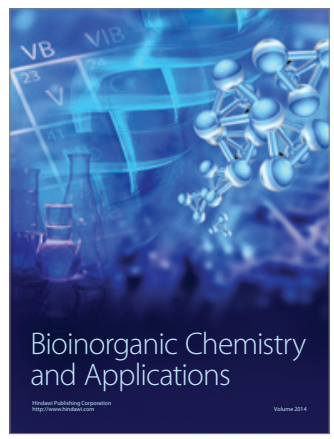

Inorganic Chemistry
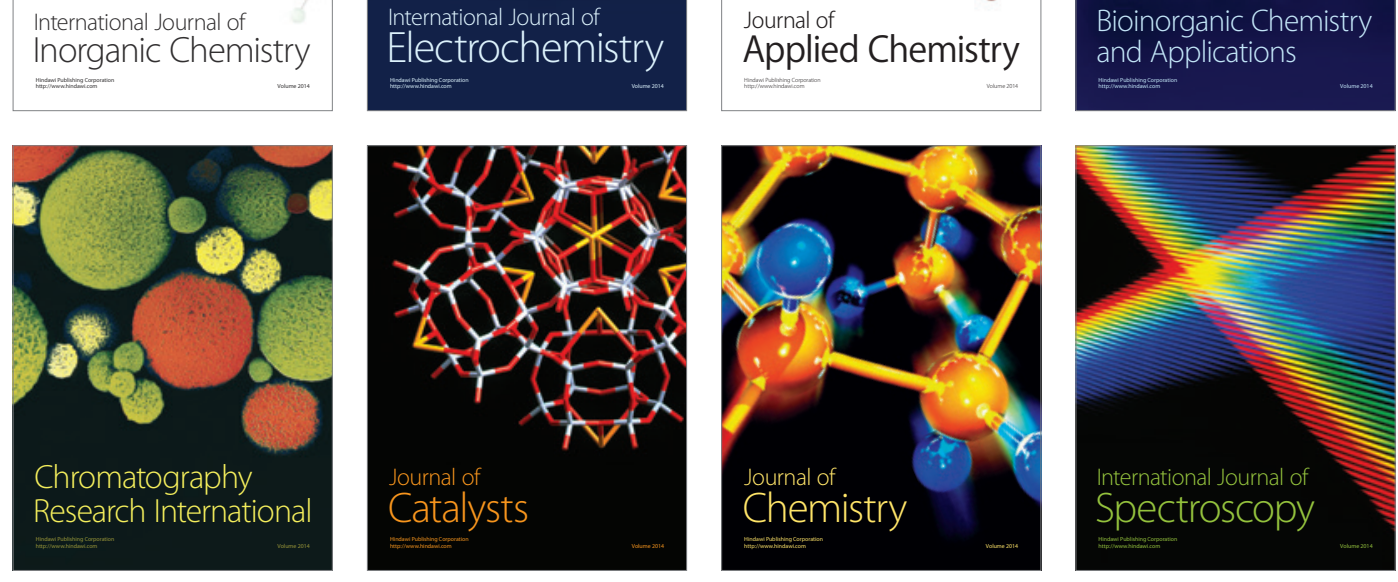